\title{
Exposure to antimuscarinic medications for treatment of overactive bladder and risk of lung cancer and colon cancer
}

This article was published in the following Dove Medical Press journal:

Clinical Epidemiology

\section{Lukas Löfling \\ Anders Sundström \\ Helle Kieler \\ Shahram Bahmanyar \\ Marie Linder}

Centre for Pharmacoepidemiology, Department of Medicine, Karolinska Institute, Solna, Sweden
Correspondence: Lukas Löfling Centre for Pharmacoepidemiology, Department of Medicine, Solna, Karolinska Institutet, T2, Karolinska University Hospital, SE I7I 76 Solna, Sweden

Email lukas.lofling@ki.se
Introduction: One out of six adults has symptoms of overactive bladder (OAB). Antimuscarinic medication is the main pharmacological group used in the treatment of OAB. In preclinical studies, antimuscarinic compounds have been found to inhibit cell proliferation in lung cancer and colon cancer.

Objective: The aim of this study was to investigate the association between exposure to antimuscarinic medication and the risk of lung cancer and colon cancer.

Methods: Individuals in Sweden who first filled a prescription for an antimuscarinic medication used to treat OAB (ie, oxybutynin, solifenacin, darifenacin, fesoterodine, or tolterodine) between July 1, 2006, and December 31, 2012, were identified and classified as exposed. Each exposed individual was individually matched with up to ten unexposed individuals from the Swedish general population, based on year of birth, sex, and county of residence. Cox proportional hazard models with follow-up time as the underlying time scale were used to estimate HRs with 95\% CIs.

Results: In total, 164,000 exposed and 1,446,472 unexposed individuals were included in this study. The estimated HRs for lung cancer, in follow-up time intervals of $<1$ year, 1-4 years, and $\geq 4$ years, were as follows: 0.86 (95\% CI: 0.75-0.98), 0.63 (95\% CI: $0.56-0.70)$, and 0.43 (0.34-0.55), respectively. The corresponding estimates for colon cancer were as follows: 0.91 (95\% CI: 0.80-1.03), 0.81 (95\% CI: 0.74-0.88), and 0.61 (95\% CI: 0.51-0.73), respectively.

Conclusion: There was an inverse association between exposure to antimuscarinic medications, used in the treatment of $\mathrm{OAB}$, and a diagnosis of colon cancer or lung cancer, which is in line with the findings in preclinical studies.

Keywords: overactive bladder, antimuscarinic medications, lung cancer, colon cancer

\section{Introduction}

Overactive bladder (OAB) is defined as urgency with or without incontinence, usually with frequency and nocturia. ${ }^{1}$ One out of six adults has symptoms of OAB, and the prevalence increases with age and is more common among women than among men. ${ }^{2,3}$ Alzheimer's disease, previous stroke, overweight, and obesity are important risk factors for OAB., ${ }^{4,5}$

Antimuscarinic medication is the main pharmacological group used in the treatment of OAB, and the selected study medications are solely approved for OAB in Sweden. ${ }^{6}$ Antimuscarinic medications can also be used in other conditions, eg, asthma. They act by blocking acetylcholine from binding to the muscarinic receptors present on the detrusor muscle, resulting in a decreased contraction of the bladder. ${ }^{6,7}$ In preclinical 
studies, activation of the muscarinic receptor subtype 3 (M3) by acetylcholine, or other M3-receptor agonists, has been shown to affect cell proliferation and cancer cell growth in prostate, colon, pancreatic, lung, brain, breast, ovarian, skin (melanocytes), stomach, bone, and blood (lymphoma and leukemia). ${ }^{8-21}$ Preclinical studies have also shown that inhibition of the M3-receptor by antagonists inhibits cell proliferation in lung cancer (both small-cell lung cancer and non-small-cell lung cancer) and colon cancer. ${ }^{22-26}$ These findings suggest that muscarinic antagonists may have an inhibitory effect on cell proliferation and cancer cell growth in the lung and colon in humans.

Smoking, exposure to radon and asbestos, and genetic factors are well-established risk factors for lung cancer. ${ }^{28}$ Inflammatory intestinal conditions, diet, a sedentary lifestyle, obesity smoking, and alcohol are risk factors for colon cancer. ${ }^{29,30}$

To the best of our knowledge, this is one of the first studies with data from population-based registers investigating the association between antimuscarinics for OAB and the risk of lung cancer and colon cancer. ${ }^{27}$ A Danish study, including 72,917 patients, investigated the association between antimuscarinic medications for OAB and different cancers, including lung cancer and colon cancer, and estimated age- and sex-standardized incidence rates (SIRs) for the associations, and the findings indicated a protective effect. ${ }^{27}$ However, as SIRs are less precise measures as compared to HRs, we will use HRs to assess associations between exposure to antimuscarinics and the risk of lung cancer and colon cancer.

The aim of the study was to investigate the association.

\section{Patients and methods Study population}

The exposed individuals in the study population were patients in Sweden who first filled a prescription for an antimuscarinic medication used to treat OAB (ie, oxybutynin, solifenacin, darifenacin, fesoterodine, or tolterodine) between July 1, 2006, and December 31, 2012. A new user was defined as a patient who filled the first prescription for a study medication, without a filled prescription for a study medication during the previous 12 months. The first filled prescription had to be for a tablet formulation to enable calculation of accumulated use.

To ensure a homogeneous study population, only antimuscarinic medications solely approved for the treatment of OAB were included.

Each exposed eligible individual was individually matched with up to ten unexposed individuals with the same characteristics such as year of birth, sex, county of residence, and vital status.

Individuals, both exposed and unexposed, younger than 18 years at the time of the first filled prescription, with a history of lung cancer or colon cancer at any time before the first filled prescription, were excluded from the study cohort. A look back period of 5 years was used to identify comorbid conditions.

\section{Data sources}

All Swedish residents are assigned a unique personal identification number (PIN) at birth or upon immigration, which is kept unchanged throughout life. ${ }^{31,32}$ The information from the different registers was linked using the PIN.

Data on filled prescriptions were obtained from the Swedish Prescribed Drug Register (PDR) with information available from July 2005, on filled prescriptions from community pharmacies. The PDR contains information on the substance name, product name, formulation, amount, date of prescribing and date of filling the prescription, and the prescriber's profession. ${ }^{33}$ The PDR does not include data on over-the-counter medications or medications on requisition used in hospitals or nursing homes.

The Swedish Cancer Register (SCR) was used to identify individuals with a diagnosis of lung cancer or colon cancer, both for exclusion and to identify the end points. The SCR was established in 1958 and records individual data on all newly diagnosed malignant tumors in Sweden. ${ }^{34}$ The register uses the ICD 7th revision (ICD-7). Since 2005, the site and histological type of the cases have been coded in ICD Oncology third edition (ICD-O-3) codes. ${ }^{35}$

The National Patient Register (NPR) and the PDR were used to obtain information on comorbid conditions (ie, cerebrovascular disease, COPD, diabetes mellitus [type 1 or 2], hypertension, inflammatory bowel disease, peptic ulcer disease, and obesity) for up to 5 years before the date of the first filled prescription. The data on filled prescriptions from the PDR were used as proxies for a diagnosis of hypertension, diabetes mellitus, or obesity. The specific medications used as proxies are listed in Table S1. The NPR started collecting data in 1964 and has national coverage regarding in-patient care since $1987 .{ }^{36,37}$ Since 2001, information on outpatient visits is also recorded and the coverage increased over subsequent years. Primary care is not covered in the register. For each admission, the NPR records information on health care establishment, date, duration of care, and personal data (sex, age, PIN, and place of residence) and contains a main and up to 30 contributory diagnoses using 
ICD codes. From 1997 the tenth revision of the ICD codes (ICD-10) is used in the NPR.

Information for censoring individuals who died was obtained from the Swedish Cause of Death Register (CDR). The CDR was established in 1961 and records causes of death of Swedish citizens independently of whether the death occurred in Sweden or abroad..$^{38}$ Data on income, education, and emigration were obtained from the population registers held by Statistics Sweden. ${ }^{39,40}$

\section{End points and follow-up}

Primarily, ICD-O-3 codes were used to identify the end points, and the ICD-7 codes were used in the case of missing ICD-O-3 codes. The two end points of interest were diagnoses of colon cancer (ICD-7 code 153 and ICD-O-3 code C18) and lung cancer (ICD-7 codes 162.1 and 163, and ICD-O-3 codes C34 and C39).

This was an intention-to-treat analysis and follow-up started at the date of the first filled prescription between July 1, 2006, and December 31, 2012 (index date). Followup ended on the date of one of the following events: a filled prescription for a non-tablet formulation of a study medication, death, a diagnosis of one of the cancer end points of interest, date of emigration, or on December 31, 2013, whichever occurred first. Follow-up of the unexposed individuals started on the same day as for the exposed individual they were matched to.

\section{Statistical analysis}

The standardized difference was calculated to quantify the difference in demographics and clinical characteristics between the compared groups, defined as the difference in the mean between the two groups divided by the SD. ${ }^{41}$

Continuous variables are presented with median and IQR or with mean and $\mathrm{SD}$, whereas categorical variables are presented as numbers and proportions.

Differences in the incidence of the two cancers of interest between exposed and unexposed were compared by estimating incidence rate difference (IRD) and 95\% CIs.

Cox proportional hazard models, with follow-up time as the underlying time scale, were used to estimate HRs with $95 \%$ CIs for the association between exposure and the cancer end points of interest. HRs were estimated using unadjusted, base, and fully adjusted models. The base model was adjusted for the matching variables by stratification. The full model was additionally adjusted for "a priori" selected variables, such as income, the level of attained education the year before the cohort inclusion date, and smoking status using a
COPD diagnosis or a filled prescription for smoking cessation medication during up to 5 years prior to the index date as a proxy. ${ }^{42}$ In addition, all the reported comorbidities, Charlson comorbidity index, ${ }^{43}$ history of any cancer, and the number of observations in the NPR were evaluated for inclusion in the full model and only included in the model if they changed the point estimate by at least $10 \% \cdot{ }^{44}$ Analyses were done overall, and stratum-specific by sex, follow-up time, and index year. In addition, overall analyses were performed using a 6-month lag time and a 12-month lag time. The proportional hazard assumption was tested for all analyses, and if violated, an interaction term between the exposure status and the followup time was included in the model.

A separate analysis that included only the exposed individuals was performed to compare individuals by cumulative defined daily dose (DDD) intervals ( $\leq 90,91-182,183-364$, and $\geq 365$ ). In this analysis, the person time contributed by each exposed individual was separated by subsequent and cumulative DDD intervals.

A sensitivity analysis was performed and included patients who started treatment with tolterodine, which is the most common antimuscarinic medication for the treatment of OAB in Sweden. Apart from the criteria for end of follow-up used in the main analysis, a filled prescription for a study medication other than tolterodine was added in the sensitivity analysis.

All data were analyzed with SAS statistical software version 9.4 (SAS Institute Inc., Cary, NC, USA) and STATA 14 (StataCorp LP, College Station, TX, USA).

\section{Ethical approval}

This study was approved by the regional ethical board in Stockholm, Sweden (record numbers 2014/1478-31 and 2015/1669-32).

\section{Results \\ Descriptive data}

Overall, 253,406 exposed individuals were identified in the PDR (Figure 1). Of those, 86,980 were considered to be prevalent users, 7 were excluded due to invalid data, 276 were younger than 18 years, and further 2,143 were excluded due to the diagnosis of lung cancer or colon cancer before the index date. In total, 164,000 exposed individuals were included. The exposed individuals were individually matched to a total of 1,491,548 unexposed individuals. There were $1,446,472$ unexposed individuals included in the study after applying the exclusion criteria. On average, 8.8 unexposed individuals were matched to each exposed individual. 
Filled prescription

July 1, 2006 to December 31, 2012 $n=253,406$

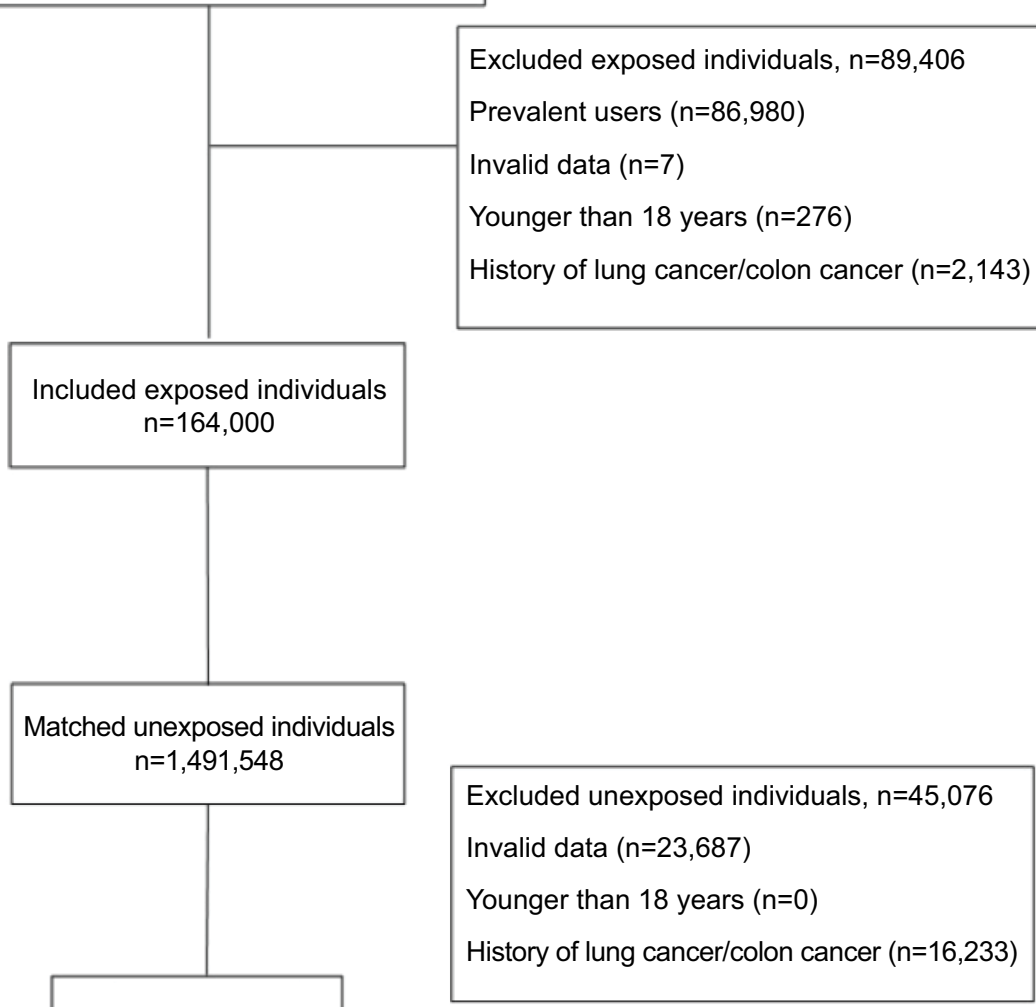

Included unexposed

individuals

$\mathrm{n}=1,446,472$

Figure I Inclusion of study population to the study cohort.

Among the exposed, $57.0 \%$ were women, with a corresponding proportion of $54.3 \%$ in the unexposed group (Table 1). The median age at index was 69 years in the exposed group and 68 years in the unexposed group. The median follow-up time, for both groups, was 47 months. A diagnosis of OAB was recorded in the NPR for $5.5 \%$ of the exposed individuals and for $1.2 \%$ of the unexposed individuals. The most common comorbid condition, in both groups, was hypertension, which was present in $45.6 \%$ of the exposed group and $39.0 \%$ in the unexposed group, with a standardized difference of $13 \%$. All the investigated comorbid conditions were more common among the exposed individuals.

\section{Outcomes}

There were $659(0.4 \%)$ and $911(0.6 \%)$ exposed individuals who developed lung cancer and colon cancer, respectively (Table 2). The corresponding numbers in the unexposed group were 8,394 (0.6\%) for lung cancer and 9,537 (0.7\%) for colon cancer. The estimated IRD for lung cancer was -44.9 per 100,000 person-years ( $95 \% \mathrm{CI}:-53.3,-36.5$ ) and for colon cancer -26.1 per 100,000 person-years (95\% CI: $-35.8,-16.3)$ (Table 1).

\section{Lung cancer}

The point estimates and 95\% CIs of the HRs for the overall analysis of lung cancer in the three different intervals with time since index date ( $<1$ year, $1-4$ years, and $\geq 4$ years) were 0.86 (95\% CI: $0.75-0.98), 0.63$ (95\% CI: $0.56-0.70)$, and $0.43(0.34-0.55)$, respectively (Table 2 ). When applying lag times, a tendency of decreasing point estimates was observed compared to the overall HRs observed in the main analysis, for which no lag time was used (Table S2).

In the stratum-specific analysis by sex, the observed point estimates of the HRs for men were all $<1$ in the follow-up time intervals ( $<1$ year, $1-4$ years, and $\geq 4$ years): 0.90 (95\% CI: $0.75-1.08), 0.62$ (95\% CI: 0.53-0.72), and 0.51 (95\% 
Table I Demographics and clinical characteristics of study subjects, both exposed and unexposed individuals

\begin{tabular}{|c|c|c|c|}
\hline Variables & Exposed & Unexposed & $d^{\mathbf{a}}$ \\
\hline Total number of individuals & 164,000 & $\mathrm{I}, 446,472$ & \\
\hline Age at index (years) & & & 0.08 \\
\hline Mean (SD) & $67(15)$ & $66(15)$ & \\
\hline Median (ql-q3) & $69(60-78)$ & $68(58-77)$ & \\
\hline Follow-up time (months) & & & 0.00 \\
\hline Mean (SD) & $47(24)$ & $47(24)$ & \\
\hline Median (ql-q3) & $47(27-68)$ & $47(27-68)$ & \\
\hline \multicolumn{4}{|l|}{ Sex, n (\%) } \\
\hline Women & $93,440(57.0)$ & $785,928(54.3)$ & 0.05 \\
\hline Men & $70,560(43.0)$ & $660,544(45.7)$ & -0.05 \\
\hline \multicolumn{4}{|l|}{ Index year, n (\%) } \\
\hline 2006-2008 & $71,057(43.3)$ & $625,357(43.2)$ & 0.00 \\
\hline $2009-2010$ & $48,060(29.3)$ & $42 I, 824(29.2)$ & 0.00 \\
\hline $2011-2012$ & $44,883(27.4)$ & $399,291(27.6)$ & 0.00 \\
\hline \multicolumn{4}{|l|}{ Education (highest completed), n (\%) } \\
\hline Mandatory or less ( $\leq 9$ years) & $39,815(24.2)$ & $366,988(25.4)$ & -0.03 \\
\hline Upper secondary ( $10-12$ years) & $55,416(33.8)$ & $494,258(34.2)$ & -0.01 \\
\hline Higher education ( $>12$ years) & $35,168(21.4)$ & $319,865(22.1)$ & -0.02 \\
\hline No educational data & $33,601(20.6)$ & $265,361(18.3)$ & 0.06 \\
\hline \multicolumn{4}{|c|}{ Income (quartiles from overall population), n (\%) } \\
\hline ql & $4 I, 137(25.1)$ & $361,367(25.0)$ & 0.00 \\
\hline q2 & $44,442(27.1)$ & $358,064(24.8)$ & 0.05 \\
\hline q3 & $4 I, 222(25.2)$ & $36 \mathrm{I}, 277(25.0)$ & 0.00 \\
\hline q4 & $36,918(22.5)$ & $365,587(25.3)$ & -0.07 \\
\hline Diagnosis of overactive bladder, n (\%) & $9,093(5.5)$ & $16,882(1.2)$ & 0.24 \\
\hline \multicolumn{4}{|l|}{ Comorbid conditions, n (\%) } \\
\hline Cerebrovascular disease & I2,538 (7.6) & $82,593(5.7)$ & 0.08 \\
\hline COPD & $4,657(2.8)$ & $33,544(2.3)$ & 0.03 \\
\hline Diabetes mellitus (type I or 2) & $19,278(11.8)$ & $|4|, 22 \mid(9.8)$ & 0.06 \\
\hline Hypertension & $74,840(45.6)$ & $563,678(39.0)$ & 0.13 \\
\hline Inflammatory bowel disease & $1,632(1.0)$ & II,524 (0.8) & 0.02 \\
\hline Peptic ulcer disease & $2,716(1.7)$ & $16,776(1.2)$ & 0.04 \\
\hline Obesity & $957(0.6)$ & $4,577(0.3)$ & 0.04 \\
\hline \multicolumn{4}{|c|}{ Incidence rate difference per 100,000 person-years } \\
\hline Lung cancer & $-44.9(95 \% \mathrm{Cl}:-53.3,-36.5)$ & & - \\
\hline Colon cancer & $-26.1(95 \% \mathrm{Cl}:-35.8,-16.3)$ & & - \\
\hline
\end{tabular}

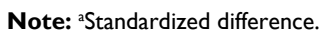

CI: 0.37-0.70), respectively (Table 2). Similar observations were found for women. The observed HRs were as follows: 0.81 (95\% CI: 0.66-0.99), 0.64 (95\% CI: 0.54-0.74), and 0.37 (95\% CI: 0.26-0.51), respectively.

When the HRs were estimated by cumulative DDD $(\leq 90$, 91-180, 181-364, and $\geq 365$ ) using the lowest group as the reference group, the observed HRs were as follows: 0.96 (95\% CI: 0.76-1.20), 1.01 (95\% CI: 0.79-1.29), and 0.82 (95\% CI: 0.67-1.00), respectively (Table 2).

In the stratum-specific analyses by groups of index years (2006-2008, 2009-2010, and 2011-2012), the observed HRs, as in the overall analysis, indicate an inverse association between fillings for antimuscarinic medications and lung cancer (Table S2).

\section{Colon cancer}

For colon cancer, the point estimates and 95\% CIs for the overall HRs for the three different intervals for time since index date ( $<1$ year, $1-4$ years, and $\geq 4$ years) were as follows: 0.91 (95\% CI: 0.80-1.03), 0.81 (95\% CI: 0.74-0.88), and 0.61 (95\% CI: $0.51-0.73$ ), respectively (Table 2 ). The observed estimated overall HRs were lower in the analyses where lag times were applied compared to the main analysis.

In the stratum-specific analyses by sex, all HRs for both men and women were $<1$. For men, the HRs in the different time intervals ( $<1$ year, $1-4$ years, and $\geq 4$ years) were as follows: 0.94 (95\% CI: $0.79-1.13), 0.81$ (95\% CI: $0.71-0.93)$, and 0.60 (95\% CI: $0.46-0.78)$, respectively (Table 2). The observed estimates for women were 0.87 (95\% 
Table 2 HRs and 95\% Cls for the end points, overall, by sex and cumulative DDD

\begin{tabular}{|c|c|c|c|c|}
\hline & $\mathbf{N}$ & Unadjusted HR (95\% Cl) & Base adjusted HR $(95 \% \mathrm{Cl})^{a}$ & Fully adjusted HR $(95 \% \mathrm{Cl})^{b}$ \\
\hline \multicolumn{5}{|l|}{ Lung cancer } \\
\hline Overall & 9,053 & & & \\
\hline Unexposed & 8,394 & I (reference) & I (reference) & I (reference) \\
\hline Exposed & 659 & & & \\
\hline$<$ I year & 234 & $0.91(0.79-1.04)$ & $0.86(0.76-0.99)$ & $0.86(0.75-0.98)$ \\
\hline $1-4$ years & 347 & $0.66(0.59-0.74)$ & $0.64(0.57-0.7 I)$ & $0.63(0.56-0.70)$ \\
\hline$\geq 4$ years & 78 & $0.47(0.37-0.59)$ & $0.44(0.35-0.55)$ & $0.43(0.34-0.55)$ \\
\hline \multicolumn{5}{|l|}{ Sex } \\
\hline Men & 4,907 & & & \\
\hline Unexposed & 4,571 & I (reference) & I (reference) & I (reference) \\
\hline Exposed & 336 & & & \\
\hline$<$ l year & 128 & $0.92(0.77-1.10)$ & $0.89(0.74-1.07)$ & $0.90(0.75-1.08)$ \\
\hline $1-4$ years & 168 & $0.63(0.54-0.73)$ & $0.61(0.52-0.72)$ & $0.62(0.53-0.72)$ \\
\hline$\geq 4$ years & 40 & $0.52(0.38-0.7 I)$ & $0.50(0.36-0.69)$ & $0.5 \mathrm{I}(0.37-0.70)$ \\
\hline Women & 4,146 & & & \\
\hline Unexposed & 3,823 & I (reference) & I (reference) & I (reference) \\
\hline Exposed & 323 & & & \\
\hline$<$ l year & 106 & $0.92(0.75-1.12)$ & $0.83(0.68-1.02)$ & $0.81(0.66-0.99)$ \\
\hline $\mathrm{I}-4$ years & 179 & $0.72(0.62-0.83)$ & $0.66(0.56-0.76)$ & $0.64(0.54-0.74)$ \\
\hline$\geq 4$ years & 38 & $0.420 .31-0.59)$ & $0.39(0.28-0.54)$ & $0.37(0.26-0.5 \mathrm{I})$ \\
\hline \multicolumn{5}{|l|}{$D D D s^{c}$} \\
\hline$\leq 90$ & 340 & I (reference) & I (reference) & I (reference) \\
\hline $91-180$ & 103 & $0.97(0.77-1.21)$ & $0.96(0.76-1.20)$ & $0.96(0.76-1.20)$ \\
\hline $18 \mid-364$ & 83 & $1.03(0.8 \mathrm{I}-1.32)$ & I.0I (0.79-1.28) & I.0I (0.79-I.29) \\
\hline$\geq 365$ & 133 & $0.83(0.68-1.02)$ & $0.82(0.67-1.00)$ & $0.82(0.67-1.00)$ \\
\hline \multicolumn{5}{|l|}{ Colon cancer } \\
\hline Overall & 10,448 & & & \\
\hline Unexposed & 9,537 & I (reference) & I (reference) & I (reference) \\
\hline Exposed & 911 & & & \\
\hline$<$ l year & 263 & $0.96(0.85-1.09)$ & $0.91(0.80-1.03)$ & $0.91(0.80-1.03)$ \\
\hline I-4 years & 508 & $0.86(0.79-0.95)$ & $0.81(0.74-0.89)$ & $0.81(0.74-0.88)$ \\
\hline$\geq 4$ years & 140 & $0.64(0.54-0.76)$ & $0.6 \mathrm{I}(0.5 \mathrm{I}-0.72)$ & $0.6 \mathrm{I}(0.5 \mathrm{I}-0.73)$ \\
\hline \multicolumn{5}{|l|}{ Sex } \\
\hline Men & 5,556 & & & \\
\hline Unexposed & 5,102 & I (reference) & I (reference) & I (reference) \\
\hline Exposed & 454 & & & \\
\hline$<$ l year & $14 \mid$ & $0.98(0.82-1.16)$ & $0.94(0.80-1.12)$ & $0.94(0.79-1.13)$ \\
\hline $1-4$ years & 250 & $0.85(0.75-0.97)$ & $0.8 \mathrm{I}(0.7 \mathrm{I}-0.93)$ & $0.8 \mathrm{I}(0.7 \mathrm{I}-0.93)$ \\
\hline$\geq 4$ years & 63 & $0.6 \mathrm{I}(0.47-0.79)$ & $0.60(0.46-0.78)$ & $0.60(0.46-0.78)$ \\
\hline Women & 4,892 & & & \\
\hline Unexposed & 4,435 & I (reference) & I (reference) & I (reference) \\
\hline Exposed & 457 & & & \\
\hline$<1$ year & 122 & $0.97(0.80-1.17)$ & $0.87(0.72-1.05)$ & $0.87(0.72-1.05)$ \\
\hline $1-4$ years & 258 & $0.90(0.79-1.02)$ & $0.80(0.70-0.91)$ & $0.80(0.70-0.91)$ \\
\hline$\geq 4$ years & 77 & $0.68(0.54-0.86)$ & $0.61(0.49-0.78)$ & $0.62(0.49-0.78)$ \\
\hline \multicolumn{5}{|l|}{$D D D s^{c}$} \\
\hline$\leq 90$ & 472 & I (reference) & I (reference) & I (reference) \\
\hline $91-180$ & 148 & I.0I (0.84-I.22) & $0.99(0.82-1.20)$ & $0.99(0.82-1.20)$ \\
\hline $18 \mid-364$ & 118 & $1.05(0.86-1.29)$ & $1.02(0.83-1.25)$ & $1.02(0.83-1.25)$ \\
\hline$\geq 365$ & 173 & $0.74(0.62-0.89)$ & $0.73(0.6 \mathrm{I}-0.87)$ & $0.73(0.61-0.87)$ \\
\hline
\end{tabular}

Notes: ${ }^{a}$ Adjusted for the matching variables age, sex, and county of residence. ${ }^{b}$ Adjusted for age, sex, and county of residence, income, education, and the smoking proxy variable. 'Only including the exposed individuals.

Abbreviation: DDD, defined daily dose. 
CI: $0.72-1.05), 0.80$ (95\% CI: $0.70-0.91)$, and $0.62(95 \%$

CI: $0.49-0.78)$, respectively.

The observed estimated HRs for the different cumulative DDD groups ( $\leq 90,91-180,181-364$, and $\geq 365$ ), using the lowest group as the reference group, were as follows: 0.99 (95\% CI: $0.82-1.20), 1.02$ (95\% CI: $0.83-1.25)$, and 0.73 (95\% CI: 0.61-0.87), respectively.

An inverse association was observed between filling a prescription for antimuscarinic medications and colon cancer for all the three index year groups (Table S2).

\section{Sensitivity analyses}

The point estimates of the HRs in the sensitivity analyses for lung cancer and for colon cancer were $<1$ in all the time intervals ( $<1$ year, $1-4$ years, and $\geq 4$ years) (Table S3). For lung cancer, the HRs were as follows: $0.84(95 \% \mathrm{CI}$ : $0.69-1.03), 0.70$ (95\% CI: $0.61-0.82)$, and 0.40 (95\% CI: $0.28-0.47)$, respectively. The corresponding estimates for colon cancer were as follows: 0.92 (95\% CI: $0.77-1.11)$, 0.90 (95\% CI: $0.80-1.02$ ), and 0.75 (95\% CI: 0.59-0.95), respectively.

\section{Discussion}

\section{Key findings}

This study observed an inverse association between filling prescriptions for antimuscarinic medications and a diagnosis of lung cancer or colon cancer. Inverse associations confirm the result from the previous Danish study, investigating the same associations and estimating SIRs. ${ }^{27}$ The inverse association was stronger with the longest follow-up time of at least 4 years. During the first year, there were in general no substantial differences between the two exposure groups and the risk of the cancers of interest. Inverse associations between both follow-up time $>1$ year and filling 365 DDDs or more and the cancers of interest were observed. This indicates that it is of no or small importance if the exposure is reported as time since treatment start or as cumulative DDDs. However, this association was more pronounced for colon cancer than for lung cancer. A possible dose-response association is consistent with results from a study based on Danish data. ${ }^{27}$ The observed estimates were on similar levels for both men and women, in both cancer types, indicating that there is no sex-based difference in the association between filling prescriptions for antimuscarinic medications and the cancer end points of interest. Similarities in observed associations between men and women are consistent with the findings from Denmark. ${ }^{27}$ The observed inverse associations are in accordance with previous findings from preclinical studies showing an inhibitory effect of antimuscarinic substances, blocking the M3-receptor, on cell proliferation and cancer cell growth in lung cancer and colon cancer cell lines. ${ }^{22,24-26}$

In the sensitivity analyses, inverse associations between exposure and lung or colon cancer were observed. The point estimates were on similar levels as observed in the main analyses, indicating no difference between the different antimuscarinic medications, demonstrating the robustness of our results.

Using no lag time for the main analysis was decided based on the preclinical studies reporting an inverse association. With an inverse association, there is no reason to suspect protopathic bias, the main reason for having a lag time. ${ }^{45}$ However, when lag times were used, the point estimates decreased, indicating a stronger inverse association. The effect of lag times was most prominent during the first year of follow-up. Our observations of a decrease in the point estimates of the effect size with longer lag time confirm the results from a similar study investigating the association between proton pump inhibitors and gastric cancer. ${ }^{45}$

Only about $6 \%$ of the exposed individuals had a recorded diagnosis of $\mathrm{OAB}$, which is likely explained by the fact that the majority of the diagnoses of $\mathrm{OAB}$ are given in primary care, which is not covered by the NPR. The overall higher prevalence of comorbid conditions among the exposed individuals could, to some extent, be due to surveillance bias.

The results of this study indicate a potential protective effect of antimuscarinic medications for $\mathrm{OAB}$ on lung cancer and colon cancer. However, further studies are required to confirm the results found in this study. The included study medications should possibly, in future studies, be studied regarding a potential cancer-protective effect.

\section{Strengths}

A major strength of this study is the use of the Swedish population-based registers with high validity and close to complete coverage of the entire Swedish population, which contributed to the quality of the study, the large sample size, and the generalizability of the results. . $^{37,46,47}$

The PDR records medications from filled prescriptions, which makes it more probable that the patient was actually exposed to the medication and eliminates the risk of recall bias regarding the exposure classification. ${ }^{48}$ However, a filled prescription does not necessarily imply the use of a medication. 


\section{Limitations}

One important limitation of this study is the lack of data on lifestyle factors such as smoking history and alcohol intake, well-known risk factors for cancer. However, the lack of information on smoking history was approached by using a diagnosis of COPD or a filled prescription for smoking cessation medication as a proxy for being a current or former smoker. However, this approach will most likely only have covered heavy smokers. The short follow-up time is also an important limitation of this study. As different cancer types have varying latency periods and the time from initiation to manifest malignancy is usually several years, ideally a long follow-up time is needed to make different assumptions about the risk of the outcome of interest and relevant exposure periods. Another possible limitation is the timing of the matching in relation to the application of exclusion criteria. The matching of unexposed individuals to the exposed individuals was done before exclusion. This lead to an uneven number of unexposed individuals matched to exposed individuals. However, this was done to avoid potential problems assigning index dates to the unexposed individuals since their index date was the same as the index date for the exposed individual they were matched to. Also, the inverse associations may to some extent be explained by the introduction of censoring due to filling a prescription of a non-tablet formulation of the study medication and as censoring only applied to the exposed individuals. It should, however, be noted that few individuals filled prescriptions for non-tablet formulations.

\section{Conclusion}

An inverse association between exposure to antimuscarinic medications, used in the treatment of $\mathrm{OAB}$, and a diagnosis of colon cancer or lung cancer was observed. However, it is important to consider the relatively short follow-up time.

\section{Acknowledgment}

The authors would like to express their gratitude to Sarah Burkill for her help with the language copy editing.

\section{Author contributions}

LL performed the statistical analysis and wrote the first draft of the manuscript. All authors contributed to data analysis, drafting or revising the article, gave final approval of the version to be published, and agree to be accountable for all aspects of the work.

\section{Disclosure}

All the authors are employees of the Centre for Pharmacoepidemiology at Karolinska Institutet, which receives grants from several funding bodies for the performance of drug safety and drug utilization studies. These funding bodies had no role in the data collection and analysis and were not involved in the interpretation of results, writing, revision, or approval of the manuscript. The authors report no other conflicts of interest in this work.

\section{References}

1. Abrams P, Cardozo L, Fall M, et al. The standardisation of terminology of lower urinary tract function: report from the standardisation subcommittee of the international continence society. Neurourol Urodyn. 2002;21(2):167-178.

2. Milsom I, Abrams P, Cardozo L, Roberts RG, Thüroff J, Wein AJ. How widespread are the symptoms of an overactive bladder and how are they managed? A population-based prevalence study. BJU Int. 2001;87(9):760-766.

3. Irwin DE, Milsom I, Hunskaar S, et al. Population-based survey of urinary incontinence, overactive bladder, and other lower urinary tract symptoms in five countries: results of the EPIC study. Eur Urol. 2006;50(6):1306-1315.

4. Dallosso HM, McGrother CW, Matthews RJ, Donaldson MM; Leicestershire MRC Incontinence Study Group. The association of diet and other lifestyle factors with overactive bladder and stress incontinence: a longitudinal study in women. BJU Int. 2003;92(1):69-77.

5. Mayo Clinic. Overactive bladder - risk factors; 2014. https://www. mayoclinic.org/diseases-conditions/overactive-bladder/symptomscauses/syc-20355715. Accessed May 22, 2016.

6. Andersson KE. Antimuscarinics for treatment of overactive bladder. Lancet Neurol. 2004;3(1):46-53.

7. Wang P, Luthin GR, Ruggieri MR. Muscarinic acetylcholine receptor subtypes mediating urinary bladder contractility and coupling to GTP binding proteins. J Pharmacol Exp Ther. 1995;273(2):959-966.

8. Rayford W, Noble MJ, Austenfeld MA, Weigel J, Mebust WK, Shah GV. Muscarinic cholinergic receptors promote growth of human prostate cancer cells. Prostate. 1997;30(3):160-166.

9. Frucht H, Jensen RT, Dexter D, Yang WL, Xiao Y. Human colon cancer cell proliferation mediated by the M3 muscarinic cholinergic receptor. Clin Cancer Res. 1999;5(9):2532-2539.

10. Spindel ER. Muscarinic receptor agonists and antagonists effects on cancer. Handb Exp Pharmacol. 2012;208:451-468.

11. Song P, Sekhon HS, Jia Y, et al. Acetylcholine is synthesized by and acts as an autocrine growth factor for small cell lung carcinoma. Cancer Res. 2003;63(1):214-221.

12. Ashkenazi A, Ramachandran J, Capon DJ. Acetylcholine analogue stimulates DNA synthesis in brain-derived cells via specific muscarinic receptor subtypes. Nature. 1989;340(6229):146-150.

13. Guizzetti M, Costa P, Peters J, Costa LG. Acetylcholine as a mitogen: muscarinic receptor-mediated proliferation of rat astrocytes and human astrocytoma cells. Eur J Pharmacol. 1996;297(3):265-273.

14. Español AJ, de La Torre E, Fiszman GL, Sales ME. Role of nonneuronal cholinergic system in breast cancer progression. Life Sci. 2007;80(24-25):2281-2285.

15. Fritz S, Wessler I, Breitling R, et al. Expression of muscarinic receptor types in the primate ovary and evidence for nonneuronal acetylcholine synthesis. J Clin Endocrinol Metab. 2001;86(1):349-354.

16. Oppitz M, Möbus V, Brock S, Drews U. Muscarinic receptors in cell lines from ovarian carcinoma: negative correlation with survival of patients. Gynecol Oncol. 2002;85(1):159-164. 
17. Batra S, Popper LD, Iosif CS. Characterisation of muscarinic cholinergic receptors in human ovaries, ovarian tumours and tumour cell lines. Eur J Cancer. 1993;29(9):1302-1306.

18. Boss A, Oppitz M, Lippert G, Drews U. Muscarinic cholinergic receptors in the human melanoma cell line SK-Mel 28: modulation of chemotaxis. Clin Exp Dermatol. 2005;30(5):557-564.

19. Wang L, Zhi X, Zhang Q, et al. Muscarinic receptor M3 mediates cell proliferation induced by acetylcholine and contributes to apoptosis in gastric cancer. Tumour Biol. 2016;37(2):2105-2117.

20. Liu PS, Chen YY, Feng CK, Lin YH, Yu TC. Muscarinic acetylcholine receptors present in human osteoblast and bone tissue. Eur J Pharmacol. 2011;650(1):34-40.

21. Kawashima K, Fujii T. Extraneuronal cholinergic system in lymphocytes. Pharmacol Ther. 2000;86(1):29-48.

22. Song P, Sekhon HS, Lu A, et al. M3 muscarinic receptor antagonists inhibit small cell lung carcinoma growth and mitogen-activated protein kinase phosphorylation induced by acetylcholine secretion. Cancer Res. 2007;67(8):3936-3944.

23. Song P, Maier M, Spindel J, Olivas A, Spindel E. Inhibition of lung cancer cell growth by tiotropium: mechanism of action In: B28. Lung Cancer Biomarkers of Risk. Am Thoracic Soc. 2009:A2675.

24. von Rosenvinge EC, Cheng $\mathrm{K}$, Drachenberg CB, et al. Bedside to bench: role of muscarinic receptor activation in ultrarapid growth of colorectal cancer in a patient with pheochromocytoma. Mayo Clin Proc. 2013;88(11):1340-1346.

25. Xu R, Shang C, Zhao J, et al. Activation of M3 muscarinic receptor by acetylcholine promotes non-small cell lung cancer cell proliferation and invasion via EGFR/PI3K/AKT pathway. Tumour Biol. 2015;36(6):4091-4100.

26. Hua N, Wei X, Liu X, et al. A novel muscarinic antagonist R2HBJJ inhibits non-small cell lung cancer cell growth and arrests the cell cycle in G0/G1. PLoS One. 2012;7(12):e53170.

27. Hallas J, Margulis AV, Pottegård A, et al. Incidence of common cancers in users of antimuscarinic medications for overactive bladder: a Danish nationwide cohort study. Basic Clin Pharmacol Toxicol. 2018;122(6):612-619.

28. Mayo Clinic [webpage on the Internet]. Lung cancer; 2018. Available from: https://www.mayoclinic.org/diseases-conditions/lung-cancer/ symptoms-causes/syc-20374620. Accessed November 19, 2018.

29. Mayo Clinic [webpage on the Internet]. Colon cancer; 2018. Available from: https://www.mayoclinic.org/diseases-conditions/colon-cancer/ symptoms-causes/syc-20353669. Accessed November 19, 2018.

30. National Cancer Institute [webpage on the Internet]. Alcohol and cancer risk; 2018. Available from: https://www.cancer.gov/about-cancer/ causes-prevention/risk/alcohol/alcohol-fact-sheet. Accessed December 7, 2018.

31. Ludvigsson JF, Otterblad-Olausson P, Pettersson BU, Ekbom A. The Swedish personal identity number: possibilities and pitfalls in healthcare and medical research. Eur J Epidemiol. 2009;24(11):659-667.

32. Furu K, Wettermark B, Andersen M, Martikainen JE, Almarsdottir AB, Sørensen HT. The Nordic countries as a cohort for pharmacoepidemiological research. Basic Clin Pharmacol Toxicol. 2010;106(2):86-94.

33. Wettermark B, Hammar N, Fored CM, et al. The new Swedish Prescribed Drug Register--opportunities for pharmacoepidemiological research and experience from the first six months. Pharmacoepidemiol Drug Saf. 2007;16(7):726-735.
34. Socialstyrelsen - Swedish National Board of Health and Welfare [webpage on the Internet]. The Swedish Cancer Register; 2017. Available from: https://www.socialstyrelsen.se/register/halsodataregister/ cancerregistret/inenglish. Accessed October 26, 2017.

35. Socialstyrelsen - Swedish National Board of Health and Welfare. Kodning i Cancerregistret - Handledning 2015. Stockholm, Sweden: Socialstyrelsen - Swedish National Board of Health and Welfare 2015.

36. Socialstyrelsen - Swedish National Board of Health and Welfare [webpage on the Internet]. The Swedish National Patient Register; 2017. Available from: https://www.socialstyrelsen.se/register/halsodataregister/patientregistret/inenglish. Accessed October 26, 2017.

37. Ludvigsson JF, Andersson E, Ekbom A, et al. External review and validation of the Swedish national inpatient register. BMC Public Health. 2011;11(1):450.

38. Socialstyrelsen - Swedish National Board of Health and Welfare [webpage on the Internet]. The Swedish Cause of Death Register; 2017. Available from: http://www.socialstyrelsen.se/register/dodsorsaksregistret. Accessed October 26, 2017.

39. Statistiska Centralbyrån (SCB) - Statistics Sweden [webpage on the Internet]. The Total Population Register; 2017. Available from: http:// www.scb.se/sv_/Vara-tjanster/Bestalla-mikrodata/Vilka-mikrodatafinns/Registret-over-totalbefolkningen-RTB/. Accessed October 26, 2017.

40. Statistiska Centralbyrån (SCB) - Statistics Sweden [homepage on the Internet]. Longitudinal integration database for health insurance and labour market studies; 2017. Available from: https://www.scb.se/cont entassets/8f66bcf5abc34d0b98afa4fcbfc0e060/rtb-bar-2016-eng.pdf. Accessed May 30, 2017.

41. Austin PC. Using the standardized difference to compare the prevalence of a binary variable between two groups in observational research. Commun Stat Simul Comput. 2009;38(6):1228-1234.

42. Terzikhan N, Verhamme KM, Hofman A, Stricker BH, Brusselle GG, Lahousse L. Prevalence and incidence of COPD in smokers and non-smokers: the Rotterdam Study. Eur J Epidemiol. 2016;31(8): 785-792.

43. Charlson ME, Pompei P, Ales KL, MacKenzie CR. A new method of classifying prognostic comorbidity in longitudinal studies: development and validation. J Chronic Dis. 1987;40(5):373-383.

44. Greenland S. Modeling and variable selection in epidemiologic analysis. Am J Public Health. 1989;79(3):340-349.

45. Tamim H, Monfared AA, Lelorier J. Application of lag-time into exposure definitions to control for protopathic bias. Pharmacoepidemiol Drug Saf. 2007;16(3):250-258.

46. Ludvigsson JF, Almqvist C, Bonamy AK, et al. Registers of the Swedish total population and their use in medical research. Eur J Epidemiol. 2016;31(2):125-136.

47. Rosén M. National health data registers: a Nordic heritage to public health. Scand J Public Health. 2002;30(2):81-85

48. Stephansson O, Granath F, Svensson T, Haglund B, Ekbom A, Kieler H. Drug use during pregnancy in Sweden - assessed by the Prescribed Drug Register and the Medical Birth Register. Clin Epidemiol. 2011;3: 43-50 


\section{Supplementary materials}

Table SI ATC codes used to identify medications in the PDR used as disease proxies

\begin{tabular}{|l|l|}
\hline Diseases & ATC codes \\
\hline Hypertension & C02, C03, C07AA0I-C07AA06, C07AA08, C07AA27, C07AB, C07Ag, C08, and C09 \\
Diabetes mellitus & A10 \\
Obesity & A09 \\
\hline
\end{tabular}

Abbreviation: ATC, Anatomic Therapeutic Chemical classification system; PDR, Prescribed Drug Register.

Table S2 HR and 95\% Cls for the end points, overall using 6-month and I2-month lag time, and by inclusion year using no lag time

\begin{tabular}{|c|c|c|c|c|}
\hline \multicolumn{5}{|l|}{ Lung cancer } \\
\hline & $\mathbf{n}$ & Unadjusted HR (95\% Cl) & Base adjusted HR $(95 \% \mathrm{Cl})^{\mathrm{a}}$ & Fully adjusted $\mathrm{HR}(95 \% \mathrm{Cl})^{\mathrm{b}}$ \\
\hline \multicolumn{5}{|c|}{ 6-month lag time } \\
\hline Overall & 7,756 & & & \\
\hline Unexposed & 7,226 & I (reference) & I (reference) & I (reference) \\
\hline Exposed & 530 & & & \\
\hline$<$ l year & 176 & $0.74(0.63-0.88)$ & $0.70(0.60-0.82)$ & $0.70(0.60-0.82)$ \\
\hline $1-4$ years & 311 & $0.68(0.61-0.76)$ & $0.65(0.58-0.73)$ & $0.64(0.57-0.72)$ \\
\hline$\geq 4$ years & 43 & $0.36(0.26-0.48)$ & $0.33(0.24-0.45)$ & $0.33(0.24-0.45)$ \\
\hline \multicolumn{5}{|c|}{ I 2-month lag time } \\
\hline Overall & 6,532 & & & \\
\hline Unexposed & 6,107 & I (reference) & I (reference) & I (reference) \\
\hline Exposed & 425 & & & \\
\hline$<$ I year & 139 & $0.64(0.54-0.76)$ & $0.62(0.52-0.74)$ & $0.62(0.52-0.74)$ \\
\hline $\mathrm{I}-4$ years & 258 & $0.66(0.58-0.75)$ & $0.63(0.55-0.7 I)$ & $0.6 \mathrm{I}(0.54-0.70)$ \\
\hline$\geq 4$ years & 28 & $0.34(0.23-0.50)$ & $0.31(0.21-0.46)$ & $0.30(0.21-0.45)$ \\
\hline \multicolumn{5}{|l|}{ Index year } \\
\hline $2006-2008$ & 5,663 & & & \\
\hline Unexposed & 5,237 & I (reference) & I (reference) & I (reference) \\
\hline Exposed & 426 & & & \\
\hline$<1$ year & 103 & $0.81(0.66-0.99)$ & $0.78(0.63-0.95)$ & $0.77(0.62-0.94)$ \\
\hline $1-4$ years & 245 & $0.78(0.68-0.89)$ & $0.75(0.66-0.86)$ & $0.75(0.66-0.86)$ \\
\hline$\geq 4$ years & 78 & $0.50(0.40-0.63)$ & $0.47(0.37-0.60)$ & $0.47(0.37-0.59)$ \\
\hline 2009-2010 & 2,345 & & & \\
\hline Unexposed & $2,18 \mid$ & I (reference) & I (reference) & I (reference) \\
\hline Exposed & 164 & & & \\
\hline$<$ l year & 74 & $1.02(0.80-1.30)$ & $0.97(0.76-1.23)$ & $0.97(0.76-1.24)$ \\
\hline $\mathrm{I}-4$ years & 90 & $0.56(0.45-0.69)$ & $0.53(0.43-0.65)$ & $0.5 \mathrm{I}(0.4 \mathrm{I}-0.63)$ \\
\hline$\geq 4$ years & 0 & - & - & - \\
\hline $201 \mathrm{I}-2012$ & 1,045 & & & \\
\hline Unexposed & 976 & I (reference) & I (reference) & I (reference) \\
\hline Exposed & 69 & & & \\
\hline$<$ l year & 57 & $0.97(0.74-1.28)$ & $0.92(0.70-1.21)$ & $0.91(0.69-1.20)$ \\
\hline $\mathrm{I}-4$ years & 12 & $0.24(0.14-0.43)$ & $0.24(0.14-0.42)$ & $0.23(0.13-0.42)$ \\
\hline$\geq 4$ years & 0 & - & - & - \\
\hline \multicolumn{5}{|l|}{ Colon cancer } \\
\hline & $\mathbf{n}$ & Unadjusted HR (95\% Cl) & Base adjusted HR $(95 \% \mathrm{Cl})^{a}$ & Fully adjusted HR $(95 \% \mathrm{Cl})^{b}$ \\
\hline \multicolumn{5}{|c|}{ 6-month lag time } \\
\hline Overall & 9,094 & & & \\
\hline Unexposed & 8,315 & I (reference) & I (reference) & I (reference) \\
\hline Exposed & 779 & & & \\
\hline$<1$ year & 242 & $0.92(0.80-1.05)$ & $0.86(0.75-0.98)$ & $0.86(0.75-0.98)$ \\
\hline I-4 years & 449 & $0.86(0.78-0.95)$ & $0.8 \mathrm{I}(0.73-0.89)$ & $0.8 \mathrm{I}(0.73-0.89)$ \\
\hline$\geq 4$ years & 88 & $0.57(0.46-0.70)$ & $0.53(0.43-0.66)$ & $0.53(0.43-0.66)$ \\
\hline
\end{tabular}

(Continued) 
Table S2 (Continued)

\begin{tabular}{|c|c|c|c|c|}
\hline \multicolumn{5}{|l|}{ Colon cancer } \\
\hline & $\mathbf{n}$ & Unadjusted HR (95\% Cl) & Base adjusted HR $(95 \% \mathrm{Cl})^{\mathrm{a}}$ & Fully adjusted HR $(95 \% \mathrm{CI})$ \\
\hline \multicolumn{5}{|c|}{ I2-month lag time } \\
\hline Overall & 7,768 & & & \\
\hline Unexposed & 7,120 & I (reference) & I (reference) & I (reference) \\
\hline Exposed & 648 & & & \\
\hline$<$ I year & 210 & $0.87(0.76-1.01)$ & $0.81(0.70-0.93)$ & $0.81(0.7 I-0.94)$ \\
\hline $1-4$ years & 392 & $0.86(0.77-0.95)$ & $0.81(0.73-0.90)$ & $0.80(0.72-0.89)$ \\
\hline$\geq 4$ years & 46 & $0.43(0.32-0.58)$ & $0.40(0.30-0.54)$ & $0.40(0.30-0.54)$ \\
\hline \multicolumn{5}{|l|}{ Index year } \\
\hline $2006-2008$ & 6,421 & & & \\
\hline Unexposed & 5,818 & I (reference) & I (reference) & I (reference) \\
\hline Exposed & 603 & & & \\
\hline$<$ I year & 109 & $0.81(0.67-0.99)$ & $0.78(0.64-0.95)$ & $0.78(0.64-0.96)$ \\
\hline $1-4$ years & 354 & $1.08(0.96-1.20)$ & $1.01(0.91-1.14)$ & $1.01(0.90-1.13)$ \\
\hline$\geq 4$ years & 140 & $0.70(0.59-0.83)$ & $0.66(0.55-0.79)$ & $0.66(0.56-0.79)$ \\
\hline 2009-2010 & 2,796 & & & \\
\hline Unexposed & 2,573 & I (reference) & I (reference) & I (reference) \\
\hline Exposed & 223 & & & \\
\hline$<$ l year & 95 & I.27 (I.03-I.58) & $1.18(0.95-1.47)$ & $1.18(0.95-1.46)$ \\
\hline $1-4$ years & 128 & $0.65(0.54-0.78)$ & $0.6 \mathrm{I}(0.5 \mathrm{I}-0.73)$ & $0.60(0.50-0.73)$ \\
\hline$\geq 4$ years & 0 & - & - & - \\
\hline $2011-2012$ & $|, 23|$ & & & \\
\hline Unexposed & $\mathrm{I}, 146$ & I (reference) & I (reference) & I (reference) \\
\hline Exposed & 85 & & & \\
\hline$<$ l year & 59 & $0.91(0.69-1.19)$ & $0.84(0.64-1.10)$ & $0.85(0.65-1.1 \mathrm{I})$ \\
\hline $1-4$ years & 26 & $0.42(0.28-0.62)$ & $0.39(0.26-0.58)$ & $0.39(0.26-0.58)$ \\
\hline$\geq 4$ years & 0 & - & - & - \\
\hline
\end{tabular}

Notes: adjusted for the matching variables age, sex, and county of residence. ${ }^{b}$ Adjusted for age, sex, and county of residence, income, education, and the smoking proxy variable.

Table S3 HR and 95\% Cls for the end points for tolterodine

\begin{tabular}{|c|c|c|c|c|}
\hline & $\mathbf{n}$ & Unadjusted HR (95\% Cl) & Base adjusted HR $(95 \% \mathrm{CI})^{\mathrm{a}}$ & Fully adjusted HR $(95 \% \mathrm{Cl})^{b}$ \\
\hline \multicolumn{5}{|l|}{ Lung cancer } \\
\hline Unexposed & 4,423 & I (reference) & I (reference) & I (reference) \\
\hline Exposed & 348 & & & \\
\hline$<$ l year & 109 & $0.88(0.72-1.07)$ & $0.84(0.69-1.03)$ & $0.84(0.69-1.03)$ \\
\hline $1-4$ years & 196 & $0.72(0.62-0.83)$ & $0.7 \mathrm{I}(0.6 \mathrm{I}-0.82)$ & $0.70(0.6 \mathrm{I}-0.82)$ \\
\hline$\geq 4$ years & 43 & $0.43(0.30-0.60)$ & $0.41(0.29-0.58)$ & $0.40(0.28-0.57)$ \\
\hline \multicolumn{5}{|l|}{ Colon cancer } \\
\hline Unexposed & 5,126 & I (reference) & I (reference) & I (reference) \\
\hline Exposed & 512 & & & \\
\hline$<$ l year & 130 & $0.97(0.8 \mathrm{I}-\mathrm{I} .17)$ & $0.92(0.77-1.1 \mathrm{I})$ & $0.92(0.77-1.1 \mathrm{I})$ \\
\hline $1-4$ years & 294 & $0.95(0.84-1.07)$ & $0.90(0.80-1.02)$ & $0.90(0.80-1.02)$ \\
\hline$\geq 4$ years & 88 & $0.74(0.59-0.94)$ & $0.75(0.59-0.95)$ & $0.75(0.59-0.95)$ \\
\hline
\end{tabular}

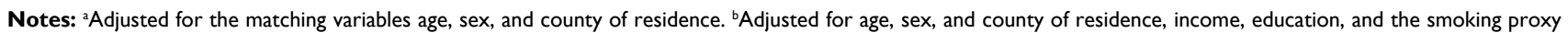
variable.

\section{Clinical Epidemiology}

\section{Publish your work in this journal}

Clinical Epidemiology is an international, peer-reviewed, open access, online journal focusing on disease and drug epidemiology, identification of risk factors and screening procedures to develop optimal preventative initiatives and programs. Specific topics include: diagnosis, prognosis, treatment, screening, prevention, risk factor modification,

\section{Dovepress}

systematic reviews, risk and safety of medical interventions, epidemiology and biostatistical methods, and evaluation of guidelines, translational medicine, health policies and economic evaluations. The manuscript management system is completely online and includes a very quick and fair peer-review system, which is all easy to use. 